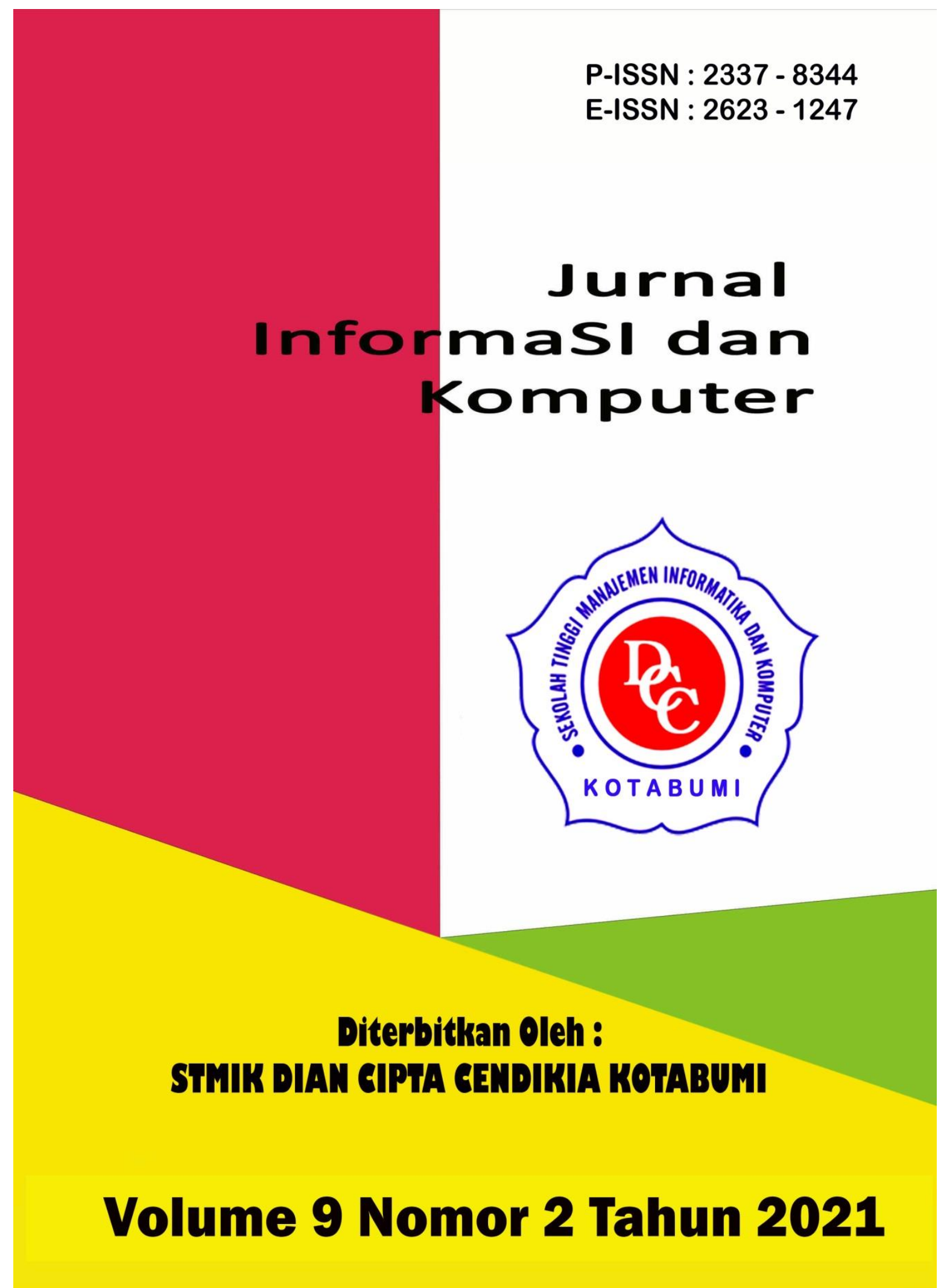




\section{Penerbit}

\section{Lembaga Penelitian STMIK Dian Cipta Cendikia Kotabumi}

Hak atas naskahh/tulisan tetap berada pada penulis, isi diluar tangung jawab penerbit dan Dewan Penyunting

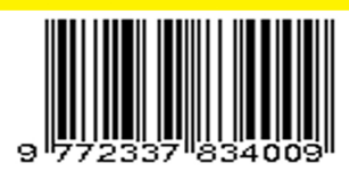




\section{PENGANTAR REDAKSI}

Puji syukur dipanjatkan kehadirat Tuhan Yang Maha Esa, atas karunia dan limpahan rahmatNYA jualah Jurnal Informasi dan komputer (JIK) STMIK Dian Cipta Cendikia Kotabumi ini dapat terwujud.Jurnal Informasi dan Komputer (JIK) yang terbit dua (2) kali dalam setahun ini merupakan suatu wadah untuk penyebar luasan hasil-hasil penelitian, studi pustaka, karya ilmiah yang berkaitan dengan Informasi dan Komputer khususnya bagi dosen-dosen STMIK Dian Cipta Cendikia Kotabumi serta umumnya para cendikiawan, praktisi, peneliti ilmu Informatika dan Komputer.

Harapan, dengan diterbitkannya Jurnal Informasi dan Komputer (JIK) ini sebagai salah satu bentuk sumbangan pemikiran dalam pengembangan ilmu informatika dan komputer yang berkaitan dengan kajian-kajian di bidang tekhnologi Informatik, Komunikasi Data dan Jaringan Komputer, perancangan dan Rekayasa Perangkat Lunak, serta ilmu-ilmu yang terkait dengan bidang Informasi dan Komputer lainnya.

Berkenaan dengan harapan tersebut, kepada para peneliti, dosen dan praktisi yang memiliki hasil-hasil penelitian, kajian pustaka, karya ilmiah dalam bidang tersebut diatas, dengan bangga redaksi Jurnal Informasi dan Komputer (JIK) menerima naskah ringkasan untuk dimuat pada jurnal Informasi dan Komputer (JIK) STMIK Dian Cipta Cendikia Kotabumi dengan berpedoman pada penulisan naskah jurnal sebagaimana dilampirkan pada halaman belakang (Bagian kulit dalam) buku jurnal ini.

Mutu dari suatu jurnal ilmiah tidak hanya ditentukan oleh para pengelolanya saja, tetapi para penulis dan pembaca jualah yang mempunyai peranan besar dalam meningkatkan mutu jurnal Informatika dan Komputer ini. Merujuk pada realita ini kamu sangat mengharapkan peran aktif dari peneliti untuk bersama-sama menjaga dan memelihara keberlangsungan dari jurnal Informasi dan Komputer STMIK Dian Cipta Cendikia Kotabumi ini. Yang juga tidak kalah pentingnya dari partisipasi tersebut diatas, adalah saran dan kritik yang membangun dari pembaca yang budiman agar kiranya dapat disampaikan langsung kepada redaksi JIK. Saran dan kritik yang membangun akan dijadikan masukan dan pertimbangan yang sangat berarti guna peningkatan mutu dan kualitas Jurnal Informasi dan Komputer STMIK Dian Cipta Cendikia Kotabumi.

Tak lupa diucapkan terima kasih yang tak terhingga atas perhatian dan kerjasama dari semua pihak yang tak dapat disebutkan satu persatu hingga dapat diterbitkan nya Jurnal Informasi dan Komputer (JIK) STMIK Dian Cipta Cendikia Kotabumi. Semoga apa yang telah diperbuat untuk kebaikan akan menjadi amal ibadah, amin.

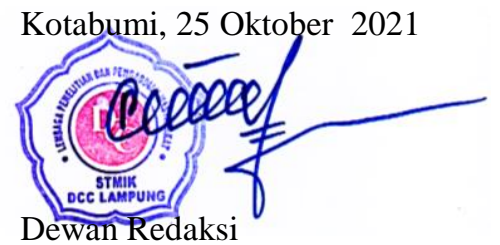




\section{JURNAL INFORMASI DAN KOMPUTER}

Volume 9 Nomor 2 Oktober 2021

Jurnal Informasi dan Komputer merupakan Sarana informasi ilmu pengetahuan, Tekhnologi dan Komunikasi yang berupa hasil penelitian, tulisan ilmiah, Ataupun studi pustaka. Jurnal ini terbit dua kali setahun pada bulan April dan Oktober. Berisi hasil penelitian ilmiah di bidang informatika yang bertujuan untuk menghubungkan adanya kesenjangan antar kemajuan teknologi dan hasil penelitian. Jurnal ini di terbitkan pertama kali pada tahun 2013.

\section{Penanggung Jawab:}

Ketua STMIK Dian Cipta Cendikia Kotabumi

\section{Pembina:}

Ketua STMIK Dian Cipta Cendikia Kotabumi Ketua Lembaga Penelitian STMIK Dian Cipta Cendikia Kotabumi

\section{Pimpinan Redaksi}

Dwi Marisa Efendi,.S.Kom.,M.Ti

\section{Redaksi pelaksana}

Rustam,.S.Kom,.M.Ti (STMIK Dian Cipta Cendikia Kotabumi)

Nurmayanti M.Kom (STMIK Dian Cipta Cendikia Kotabumi)

Sukatmi,.S.Kom., M.Kom (AMIK DCC Bandar Lampung)

Sampurna Dadi Riskiono,M.Kom (Universitas Teknokrat Indonesia)

Ifo Wahyu Pratama,S.Kom.,M.Ti(AMIK MASTER Lampung)

\section{Mitra Bestari}

Dr. RZ. ABDUL AZIZ, ST., MT (Institut Informatika dan Bisnis Darmajaya)

Dr. Dadang Sudrajat, S.Si, M.Kom (STMIK IKMI Cirebon)

Dr. Septafiansyah Dwi Putra, S.T., M.T (Politeknik Negeri Lampung)

Dr. Evi Grativiani, S.E., M.S.I (Universitas Sebelas Maret)

Rohmat Indra Borman ( Universitas Teknokrat Indonesia )

Ferry Wongso, S.KOm., M.Kom ( STMIK Darma Pala Riau)

Ferly Ardhy, S.Kom., M.Ti ( Universitas Aisyah Pringsewu )
Firmansyah, S.E., M.Si (STMIK Darma Pala Riau)

Amarudin (Universitas Teknokrat Indonesia) Didi Susianto, S.T., M.Kom (AMIK Dian Cipta Cendika Bandar Lampung)

Alhibarsyah, St., M.Kom (STMIK Tunas Bangsa Bandar Lampung)

Kemal Farouq Mauladi, S.Kom .M.Kom (Universitas Islam Lamongan)

Rima Mawarni, M.Kom ( STMIK Dian Cipta Cendikia Kotabumi)

Wira Jaya Hartono, S.Pd., M.Pd ( STMIK Darma Pala Riau)

Penerbit : STMIK Dian Cipta Cendikia Kotabumi Bekerja Sama Dengan LPPM STMIK Dian Cipta Cendikia Kotabumi.

\section{Alamat Redaksi/Penerbit:}

Jl. Negara No. 3 Candimas Kotabumi Lampung Utara

No Telpon/Fax 072423003

Email : 1ppm-stmik@dcc.ac.id 


\section{JURNAL INFORMASI DAN KOMPUTER VOL. 9 NO. 2 THN. 2021}

\section{DAFTAR ISI}

Halaman

Sistem Informasi Akuntansi Persedian Barang Berbasis Web Pada Lembaga

Permasyarakatan Kelas II A Banceuy Bandung : "Kelompok Tani Desa Banjar Kertarahayu” Teuku Rian Hardiyansyah, Fatia Salsa Azzahra (Politeknik Piksi Ganesha Bandung ${ }^{1,2}$ ).

Penerapan Finite State Automata Pada Vending Machine Penjual Obat Non Resep

Dokter Dan Keperluan Medis

Eko Supriyanto $^{1}$, Angga Ardiansyah ${ }^{2}$, Frieyadie $^{3}$, Sri Rahayu ${ }^{4}$, Windu Gata ${ }^{5}$

(Universitas Nusa Mandiri ${ }^{12}$ )

Sistem Pendukung Keputusan Untuk Menentukan Kelayakan Pengajuan Sertifikasi Guru Dengan Metode Simple Additive Weighting (Studi Kasus : Ma Al Muhajirin Janti Jogoroto Jombang)

Budiman, umam baharudin, winarti

(Universitas Darul 'Ulum Jombang)

Perancangan Infrastruktur Domain Name Server Lokal Menggunakan Ubuntu Server 16.04

Pada PT. Xyz

Zaenal Mutaqin Subekti, Hendra Setiawan, Satria, Widia Murni Wijaya,

Aliy Hafiz, Warsudi

(STMIK Bani Saleh, Universitas Negeri Yogyakarta, AMIK Dian Cipta Cendikia,

STMIK MIC CIkarang)

Perancangan Sistem Informasi Idea Proposal (Ip) Berbasis Web Pada Pt. Paxel Algorita Unggul

Julian Murhan Sahputra, Indah Purnamasari

(Universitas Nusa Mandiri ${ }^{12}$ )

Sistem Pendukung Keputusan Untuk Menentukan Ekstrakurikuler Atletik

Berdasarkan Bakat Siswa Menggunakan Metode Profile Matching

Agnes Basuki, Petrus Sokibi, Tiara Eka Putri

(Universitas Catur Insan Cendekia)

Penerapan Algoritma K-Means Untuk Pengelompokan Usia Calon Penerima Vaksin

Di Kab. Ngawi

Irna Yuniarfi, Saifulloh

(Universitas PGRI Madiun ${ }^{12}$ )

System Penilaian Seleksi Calon Karyawan Baru Menggunakan Metode Simple Additive Weighting (SAW) Di PT.TNA

Anik Sri Wahyuningsih, Yudhi Firmansyah

(Universitas Panca Sakti Bekasi ) 
Perancangan Sistem Informasi Pembayaran SPP Menggunakan Framework Laravel Ichwan Habib Moudi

(Universitas Panca Sakti Bekasi)

Implementasi Algoritma K-Means Dan Algoritma Apriori Optimasi Kinerja Ecu

(Study Kasus Mobil Avanza Dan Xenia)

Sigit Mintoro' Asep Afandi

(STMIK Dian Cipta Cendikia Kotabumi)

Sistem Pakar Penyakit Buah Kakao Untuk Peningkatan Hasil Panen Kakao Menggunakan

Metode Case Base Reasoning (CBR) Berbasis Web Mobile

Aliy hafiz, Verawati

(AMIK Dian Cipta Cendikia,Bandar Lampung)

Penerapan Metode Rapid Application Develomment (RAD) Dalam Pengembangan

Sistem Pemesanan Menu Berbasis Android

Aris Baihaqi, Tumini

(Fakultas Sains dan Teknologi ${ }^{1,2}$ )

Rancang Bangun Sistem Informasi Geografis Pariwisata Di Lampung Timur

Sukatmi, Rexa Alfa Rizi

(AMIK DCC Bandar Lampung ${ }^{12}$ )

Implementasi Psak No. 45 Pada Proses Penyusunan Laporan Keuangan Menggunakan

M.S. Excel Dan Aplikasi Accurate Accouting Pada STMIK Bani Saleh

Marhakim, Willy Adam

(STMIK Bani Saleh ${ }^{12}$ )

Sistem Prediksi Harga KOPI LAMBAR ( Lampung Barat) Dengan Metode

Backpropagation, dan Double Exponential ( Studi Kasus BUMDES )

Supriyanto, Dwi marisa Efendi,Rhomadhon

(STMIK Dian Cipta cendikia Kotabumi ${ }^{1-}$ )

Sistem Informasi Pemasaran Produk Umkm Berbasis Web Pada Kecamatan Bumi

Nabung Lampung Tengah

Yuli Syafitri, Agus Prasetyo, Reni Astika

(AMIK Dian Cipta Cendikia Bandar Lampung)

Rancang Bangun Aplikasi Pembelajaran Aksara Lampung Berbasis Android

Ferly Ardhy, Hendra Syahrobi

(Universitas Aisyah Pringewu ${ }^{1,}$ STMIK Dian Cipta Cendikia ${ }^{2}$ )

Sistem Pakar Diagnosa Penyakit Kulit Pada Balita Menggunakan Metode Naïve

Bayes Dan Forward Chaining Studi Kasus Puskesmas Cempaka Sungkai Selatan

Sidik Rahmatullah, Rima Mawarni

(STMIK Dian Cipta Cendikia Kotabumi ${ }^{12}$ )

Rekayasa Perangkat Lunak Perhitungan Harga Pokok Produksi Metode

Full Costing Pada Umkm Mitra Cake Di Bandar Lampung

Pitrawati, Arif Sanjaya

(AMIK Dian Cipta Cendikia, Bandar Lampung) 
Rancang Bangun Sistem Ujian Online Menggunakan Algoritma Cosine Similarity

Berbasis Web

Haryono, Zaenal Mutaqin Subekti, Widiyawati, Hidayatullah

(STMIK Bani Saleh ${ }^{1234}$ )

Model Aplikasi Helpdesk Ticketing System Berbasis Web Menggunakan Metode Rad

Indra Permana

Pattern Recognition Tulisan Tangan Huruf Hijaiyah Menggunakan Metode

Convolutional Neural Network (CNN)

Mufassiril Abror, Nopiyanto

(Universitas Panca Sakti Bekasi ${ }^{12}$ )

Aplikasi Sistem Informasi Keuangan Berbasis Android Di Perumahan Taman

Karang Bahagia

Melda Ayulestari

(Universitas Panca Sakti Bekasi)

Audit Pelayanan Sistem Rujukan Online Puskesmas Menggunakan Framework COBIT 5.0

Nurmayanti, Merri Parida, Ngajiyanto, Ina Anzalna

(STMIK Dian Cipta Cendikia Kotabumi ${ }^{1234}$ )

Perancangan Sistem Informasi Pengolahan Data Nilai Siswa Berbasis Web

Erin Ermawati, Anik Sri Wahyuningsih

(Fakultas Sain dan Teknologi, Universitas Panca Sakti Bekasi ${ }^{12}$ )

Pengembangan Sistem Pelaporan Data Hasil Inspeksi Barang Berbasis Web

Siska Putriani

(Universitas Pancasakti Bekasi)

Penerapan Extreme Programming Dalam Perancangan Aplikasi Web Food Market

Tumini, Hilman Septiana

(Fakultas Sains dan Teknologi Universitas Panca Sakti Bekasi ${ }^{1,2}$ )

Sistem Pencarian Barang Berbasis Website Menggunakan Php Dan Mysql

Studi Kasus PT. Surya Technology Industri Sulaeman

(Universitas Panca Sakti Bekasi)

Implementasi Metode Prototype Pada Sistem Peminjaman Alat Kerja Berbasis Web

Di PT SK Metalindo

Ali Mulyanto, Arjun Gunawan

(Univeritas Panca Sakti Bekasi)

Aplikasi Tata Cara Wudhu Menggunakan Teknologi Augmented Reality

Sebagai Media Pembelajaran Di TK Al Fatih

Ahmad Yakub, Idarul Fadli

(Universitas Panca Sakti Bekasi ${ }^{12}$ )

Sistem Pakar Diagnosa Penyakit Ayam Petelur Menggunakan Metode Certainty Factor

Berbasis Web Mochammad

Taufiq Hidayat, Ali Mulyanto

(Universitas Panca Sakti Bekasi ${ }^{12}$ ) 
Penerapan Metode Prototyping Dalam Perhitungan Hasil Produksi Menggunakan

Arduino Uno R3 Dan Php Di PT. Indonesia Epson Industry

Amandha Aulia, Ajar Rohmanu

(Universitas Panca Sakti Bekasi ${ }^{12}$ )

System Pendukung Keputusan Penentuan Guru Teladan Dengan Metode Profile Matching

Hasbulloh, Agmawarnida

(Universitas Panca Sakti Bekasi ${ }^{1,2}$ )

Implementasi Waterfall Method Pada Aplikasi Buku Induk Siswa Berbasis Web

Idam Holid, Yogie Krisnayadi

(Universitas Panca Sakti ${ }^{12}$ )

Pengembangan Text To Speech Media Pembelajaran Untuk Pengenalan

Anggota Tubuh Manusia Kelas V Sekolah Dasar

Juwanda Saputra, Ali Mulianto

(Teknik Infomratika Fakulutas Sains dan Teknologi ${ }^{12}$ )

Perancangan Sistem Peminjaman Barang Berupa Aset Tetap Berbasis Web

Pada Lembaga Permasyarakatan Kelas II A Banceuy Bandung

Guntur Salasa Priambodo, Perwito, Candra Mecca Sufyana

(Politeknik Piksi Ganesha Bandung ${ }^{1,2,3}$ )

Metode Pemilihan Karyawan Terbaik Sebagai Penentu Goodwill Perguruan Tinggi

Dengan Menggunakan Metode Topsis (Studi Kasus Perguruan Tinggi Di Lampung Utara)

Dwi Sartika, Pakarti Riswanto

(STMIK Dian Cipta Cendikia Kotabumi)

Sistem Pendukung Keputusan Pemilihan Merek Smartphone Menggunakan

Metode Analytical Hierarchy Process (AHP)

Ade Kiki Fatmawati, Muhammad Sultan Raflie, Norma Yunita

(Universitas Nusa Mandiri ${ }^{123}$ )

Pattern Recognition Aksara Lampung Menggunakan Algoritma Neural Network

Metode Analytical Hierarchy Process (AHP)

Nopiyanto, Rahmadi

(Universitas Panca Sakti Bekasi) 


\title{
PENERAPAN METODE RAPID APPLICATION DEVELOMMENT (RAD) DALAM PENGEMBANGAN SISTEM PEMESANAN MENU BERBASIS ANDROID
}

\author{
Aris Baihaqi ${ }^{1}$, Tumini $^{2}$ \\ Fakultas Sains dan Teknologi ${ }^{1,2}$ \\ Universitas Panca Sakti Bekasi ${ }^{1,2}$ \\ Email : arisbhq@gmail.com ${ }^{1}$, kemuningijo@gmail.com²
}

\begin{abstract}
ABSTRAK
Penyebaran virus corona secara global, masih terus bertambah dari hari ke harinya. Tidak terkecuali di Indonesia jumlah angka positif terinfeksi Virus Covid-19 semakin hari semakin meningkat, meski angka kesembuhan semakin menunjukan peningkatan pula setiap hari nya. Adanya himbauan dari Pemerintah mengenai penerapan 3M (Mencuci tangan, Memakai masker, Menjauhi kerumunan), salah satu yang terkena dampaknya adalah para penjual kedai kopi yang hanya mengandalkan bertatap muka antara pembeli mengalami penurunan omzet dan pendapatan, karena masyarakat diharuskan untuk mengerjakan berbagai kegiatan di rumah baik bekerja, bersekolah maupun dalam melakukan kegiatan sosial. Perkembangan perangkat mobile memberikan manfaat yang sangat besar bagi kehidupan masyarakat, terlebih saat menghadapi kondisi saat ini, dimana seluruh dunia dihadapkan pada pandemi covid-19. Belanja secara online adalah cara cerdas memanfaatkan perkembangan perangkat mobile secara positif disaat maraknya pandemi covid-19. Penelitian ini bertujuan untuk merancang bangun suatu aplikasi pemesanan menu pada kedai kopi berbasis android yang dimana menggunakan metode RAD (Rapid Application Development).
\end{abstract}

Keywords : pemesanan menu, kedai kopi, metode RAD.

\begin{abstract}
The spread of the corona virus globally is still increasing day by day. Indonesia is no exception, the number of positive numbers infected with the Covid-19 virus is increasing day by day, although the recovery rate is also increasing every day. There is an appeal from the Government regarding the application of $3 M$ (Washing hands, Wearing masks, Staying away from crowds), one of the affected is coffee shop sellers who only rely on face-to-face contact with buyers experiencing a decrease in turnover and income, because people are required to do various activities at home either at work, in school or in social activities. The development of mobile devices provides enormous benefits for people's lives, especially when facing current conditions, where the whole world is faced with the COVID-19 pandemic. Online shopping is a smart way to take advantage of the development of mobile devices in a positive way during the COVID-19 pandemic. This study aims to design a menu ordering application at an Androidbased coffee shop which uses the RAD method (Rapid Application Development).
\end{abstract}

Keywords : menu ordering, coffee shop, RAD method.

\section{PENDAHULUAN}

Covid-19 merupakan jenis virus yang diidentifikasi sebagai penyebab penyakit pada saluran pernapasan, yang pertama kali terdeteksi muncul di Kota Wuhan, Tiongkok pada akhir 2019, terus berlanjut hingga penyebaran virus Corona mewabah ke seluruh dunia Wabah Covid-19 kini menjadi pandemi global setelah diumumkan oleh Badan Kesehatan Dunia (WHO). Penyebaran virus corona secara global, masih terus bertambah dari hari ke harinya. Tidak terkecuali di Indonesia jumlah angka positif terinfeksi Virus Covid-19 semakin hari semakin meningkat, meski angka kesembuhan semakin menunjukan peningkatan setiap hari nya. Adanya himbauan dari Pemerintah mengenai penerapan 3M (Mencuci tangan, Memakai masker, Menjauhi kerumunan), salah satu yang terkena dampaknya adalah para penjual kedai kopi yang hanya mengandalkan bertatap muka antara pembeli mengalami penurunan omzet 
dan pendapatan, karena masyarakat diharuskan untuk mengerjakan berbagai kegiatan di rumah baik bekerja, bersekolah maupun dalam melakukan kegiatan sosial.

Di era revolusi industri 4.0 saat ini, teknologi memainkan peran penting dalam kehidupan manusia, perkembangan perangkat mobile memberikan manfaat yang sangat besar bagi kehidupan masyarakat, terlebih saat menghadapi kondisi saat ini, dimana seluruh dunia dihadapkan pada pandemi covid-19. Belanja secara online adalah cara cerdas memanfaatkan perkembangan perangkat mobile secara positif disaat maraknya pandemi covid-19. Mulai dari makanan pokok hingga bahan kebutuhan lainnya, hanya dengan ponsel masing-masing semua dapat berselancar untuk menemukan apa yang dibutuhkannya.

Dengan menggunakan ponsel pintar yang berbasis Android dapat mempercepat proses pemesanan. Android mempunyai banyak kelebihan, salah satunya adalah Open Source. Sehingga banyak kalangan developer yang mengembangkan aplikasi pada platform ini. Hanya dengan memilih menu yang ada pada smartphone maka pesanan sudah tersampaikan pada server yang kemudian akan ditampilkan pada smartphone yang tersedia selanjutnya pesanan akan diproses dan akan diteruskan kepada pelayan untuk diantarkan kepada pelanggan sesuai dengan pesanannya. Oleh sebab itu berdasarkan permasalahan diatas penulis tertarik untuk melakukan penelitian terhadap teknologi tersebut dengan harapan dapat dilakukan pengembangan pada tahapan selanjutnya. Oleh karena itu, dalam penyusunan Tugas Akhir ini penulis mengambil judul "Penerapan Metode Rapid Application Development (RAD) Dalam Pengembangan Sistem Pemesanan Menu Berbasis Android".

Adapun tujuan yang ingin didapat oleh penulis dari hasil penelitian ini adalah:

1. Membuat aplikasi yang mampu melakukan transaksi secara delivery ataupun takeaway guna mengurangi angka penyebaran virus Corona.

2. Membuat aplikasi yang mampu mempercepat waktu pemesanan.

3. Dapat merekap laporan transaksi penjualan secara online.

\section{METODE PENELITIAN}

Rapid Application Development (RAD) adalah salah satu metode pengembangan suatu sistem informasi dengan waktu yang relatif singkat. Untuk pengembangan suatu sistem informasi yang normal membutuhkan waktu minimal 180 hari, akan tetapi dengan menggunakan metode RAD suatu sistem dapat diselesaikan hanya dalam waktu 30-90 hari. Tujuan utama dari semua metode sistem development adalah memberikan suatu sistem yang dapat memenuhi harapan dari para pemakai, akan tetapi sering kali di dalam melakukan pengembangan suatu sistem tidak melibatkan para pemakai sistem secara langsung, sehingga hal ini menyebabkan sistem informasi yang dibuat jauh dari harapan pemakai yang dapat berakibat sistem tersebut walaupun dapat diterima tetapi para pemakai enggan untuk menggunakannya atau bahkan para pemakai menolak untuk menggunakannya. Pada saat RAD diimplementasikan, maka para pemakai bisa menjadi bagian dari keseluruhan proses pengembangan sistem dengan bertindak sebagai pengambil keputusan pada setiap tahapan pengembangan. RAD bisa menghasilkan suatu sistem dengan cepat karena sistem yang dikembangkan dapat memenuhi keinginan dari para pemakai sehingga dapat mengurangi waktu untuk pengembangan ulang setelah tahap implementasi. ( Noertjahyana, 2002)

\section{Keuntungan metode RAD}

Beberapa keuntungan dalam menggunakan metode RAD adalah sebagai berikut:

- Membeli sistem yang baru memungkinkan untuk lebih menghemat biaya ketimbang mengembangkan sendiri.

- Proses pengiriman menjadi lebih mudah, hal ini dikarenakan proses pembuatan lebih banyak menggunakan potonganpotongan script.

- Mudah untuk diamati karena menggunakan model prototype, sehingga user lebih mengerti akan sistem yang dikembangkan.

- Lebih fleksibel karena pengembang dapat melakukan proses desain ulang pada saat 
yang bersamaan.

\section{Kekurangan metode RAD}

Beberapa kerugian dalam menggunakan metode RAD adalah sebagai berikut :

- Dengan melakukan pembelian belum tentu bisa menghemat biaya dibandingkan dengan mengembangkan sendiri.

- Membutuhkan biaya tersendiri untuk membeli peralatan-peralatan penunjang seperti misalnya software dan hardware.

- Kesulitan melakukan pengukuran mengenai kemajuan proses.

- Kurang efisien karena apabila melakukan pengkodean dengan menggunakan tangan bisa lebih efisien.

- Ketelitian menjadi berkurang karena tidak menggunakan metode yang formal dalam melakukan pengkodean.

\section{Tahapan-tahapan RAD}

Dalam metode RAD terdapat langkah - langkah yang dibagi dalam empat fase. Langkah-langkah metode RAD adalah sebagai berikut:

\section{Rencana Kebutuhan (Requirement Planning)}

Rencana Kebutuhan (Requirement Planning) merupakan fase user dan analyst melakukan pertemuan untuk mengidentifikasi tujuan dari sistem dan kebutuhan informasi untuk mencapai tujuan. Pada tahap ini merupakan hal terpenting yaitu adanya keterlibatan dari kedua belah pihak. Hasil atau Output dari proses ini berupa laporan penelitian dari pengembangan aplikasi, analisis spesifikasi awal, analisis persyaratan user dan sistem, dan informasi fitur pada aplikasi pemesanan menu. Dalam proses ini sumber daya yang digunakan yaitu komputer dan handphone dengan koneksi internet, buku literatur dan user sebagai responden untuk mengetahui respon terhadap aplikasi pemesanan menu yang akan dikembangkan. Berikut tahapan-tahapan pada fase ini.

\section{Proses Desain Sistem (Design System)}

Tahapan berikutnya adalah fase analisis model Pada tahap ini keaktifan user yang terlibat menentukan untuk mencapai tujuan karena pada proses ini melakukan proses desain dan melakukan perbaikan-perbaikan apabila masih terdapat ketidaksesuaian desain antara user dan analyst. Seorang user dapat langsung memberikan komentar apabila terdapat ketidaksesuaian pada desain, merancang sistem dengan mengacu pada dokumentasi kebutuhan user yang dibuat pada tahap sebelumnya.Yang mana proses yang dilakukan dimulai dari mengidentifikasi aktor dan use case dengan merancang aplikasi yang akan dikembangkan, menggambarkan aliran control untuk mengetahui hubungan aktor dan objek, menggambarkan komunikasi antar objek dan aktor, menggambarkan perubahan keadaan suatu objek pada aplikasi kelas tertentu, memodelkan perilaku use case serta objek pada aplikasi dan menggambarkan perubahan suatu objek pada kelas tertentu. Masukan pada tahapan ini yaitu informasi aplikasi pada penelitian sebelumnya, data - data hasil dari tahapan Fase 1: Analisis Persyaratan dan metode yang akan digunakan pada fase berikutnya.

\section{Implementasi (Implementation)}

Tahapan ini adalahan tahapan programmer yang mengembangkan desain suatu program yang telah disetujui oleh user dan analyst. Sebelum diaplikasikan pada suatu organisasi terlebih dahulu

dilakukan proses pengujian terhadap program tersebut apakah ada kesalahan atau tidak. Pada tahap ini user biasa memberikan tanggapan akan sistem yang sudah dibuat serta mendapat persetujuan mengenai sistem tersebut.

\section{HASIL DAN PEMBAHASAN}

\subsection{Fase Analisa Persyaratan}

Berdasarkan hasil observasi dan pengamatan yang dilakukan, dapat dirangkum identifikasi masalah sebagai berikut:

1. Mengurangi angka penyebaran virus Corona.

2. Memenuhi kebijakan Pemerintah untuk tetap menjaga jarak dan tidak menimbulkan kerumunan.

3. Mempermudah melakukan transaksi pemesanan tanpa harus datang ke kedai. 
4. Meminimalisir terjadi kesalahan pada saat penyajian.

Batasan sistem untuk aplikasi yang akan dibuat adalah :

1 User/Pelanggan hanya dapat melakukan pemesanan pada aplikasi yang tersedia.

2 Aplikasi ini hanya berjalan pada smartphone yang menggunakan platform android.

\subsection{Fase Analisis Modeling}

User yang terlibat dalam sistem kedai kopi ini ada 2 type, yaitu user sebagai admin dan user sebagai pelanggan. Tugas dan tanggung jawab dari masingmasing user tergambar dalam tabel berikut.

Tabel 1. User dan tanggung jawab

\begin{tabular}{|c|c|}
\hline Aktor & Tugas \& Tanggung Jawab \\
\hline Admin & $\begin{array}{l}\text { 1. } \begin{array}{l}\text { Mengatur menu, berupa } \\
\text { penambahan data, edit data, } \\
\text { dan hapus data }\end{array} \\
\text { 2. } \begin{array}{l}\text { Memberikan daftar pesanan } \\
\text { pelanggan. }\end{array} \\
\text { 3. } \begin{array}{l}\text { Mencetak Struk/Tagihan } \\
\text { pelanggan }\end{array}\end{array}$ \\
\hline Pelanggan & $\begin{array}{l}\text { 1. Melihat daftar menu. } \\
\text { 2. Melihat informasi kedai } \\
\text { 3. Memesan menu } \\
\text { 4. Melihat daftar pesanan dan } \\
\text { total tagihan }\end{array}$ \\
\hline
\end{tabular}

Alur sistem informasi pemesanan makanan yang digambarkan dalam bentuk flowmap diagram menunjukkan gambaran hasil analisa sebuah bisnis proses yang telah disepakati bersama product owner, alur sistem usulan ini merupakan pengembangan dari proses yang berjalan selama ini. Berikut ini merupakan flowchart alur sistem yang diusulkan.

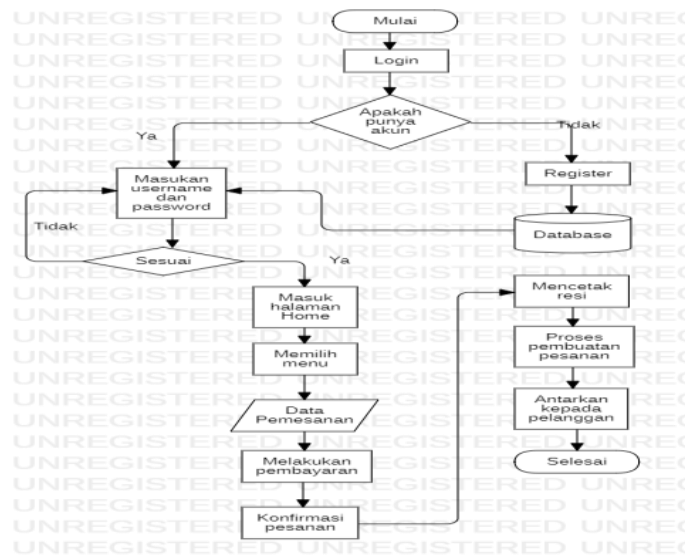

Gambar 1. Use case diagram

Use case diagram digunakan untuk menggambarkan bagaimana cara pelanggan atau aktor berinteraksi dengan sistem yang akan dibuat karena Use case diagram menggambarkan apa yang dapat dilakukan aktor terhadap sistem dan aplikasi pemesanan makanan dan minuman.

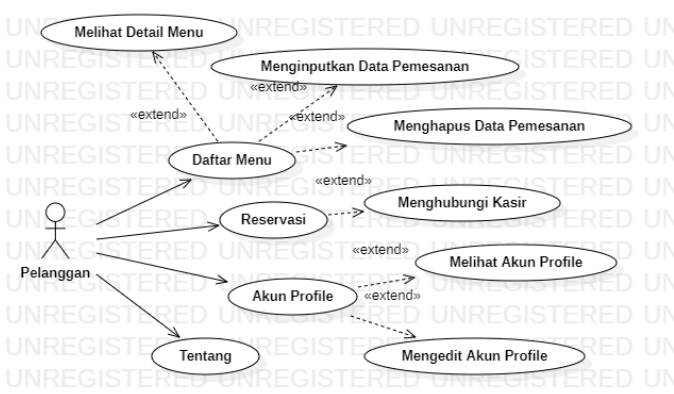

Gambar 2. Usecase diagram Pelanggan

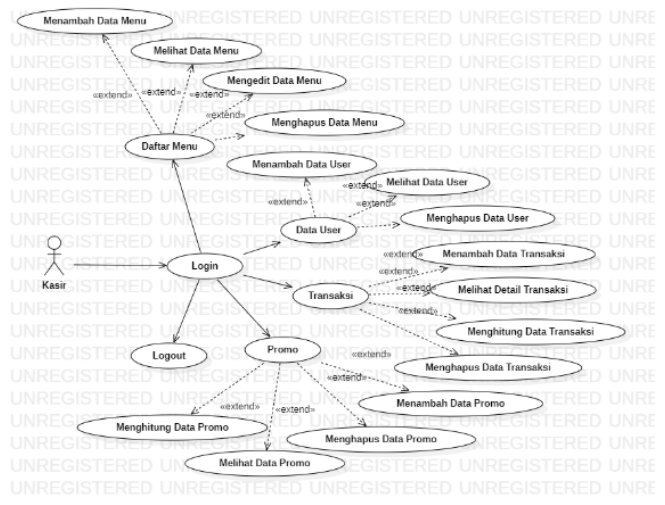

Gambar 3. Usecase diagram Kasir 
Activity diagram digunakan untuk penggambaran aktivitas aktor didalam suatu sistem. aplikasi pemesanan makanan dan minuman memiliki 3 aktor sehingga terdiri dari 3 Activity diagram.

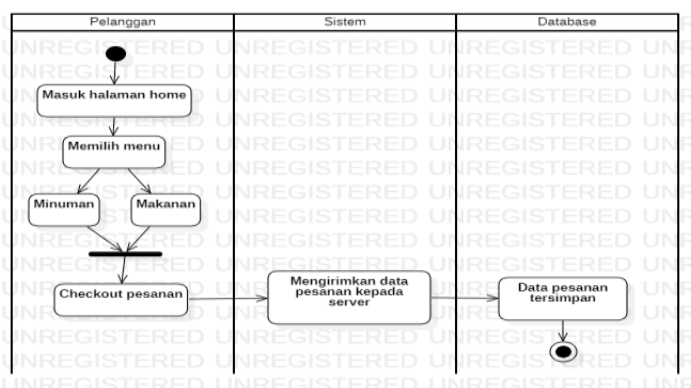

Gambar 3. Activity Diagram Pelanggan

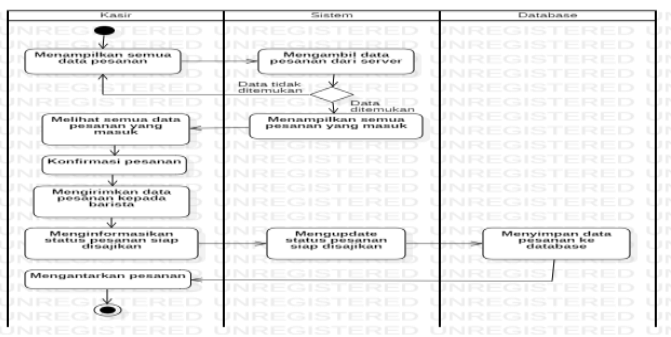

Gambar 4. Activity Diagram Kasir

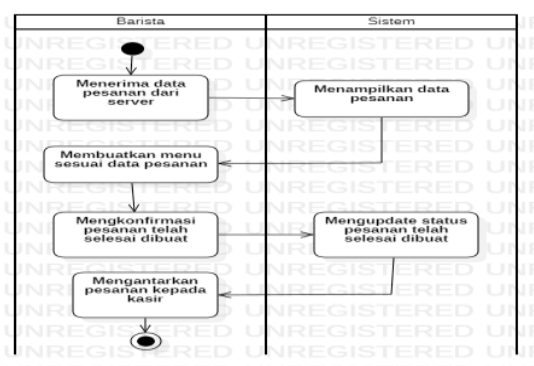

Gambar 5. Activity Diagram Barista

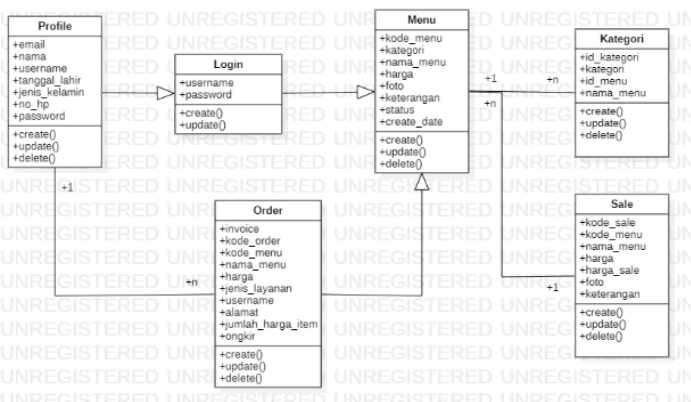

Gambar 6. Class Diagram
Class diagram menggambarkan struktur sistem dengan meodelkan kelas, atribut operasi serta hubungan antar project.

\subsection{Fase Modelling}

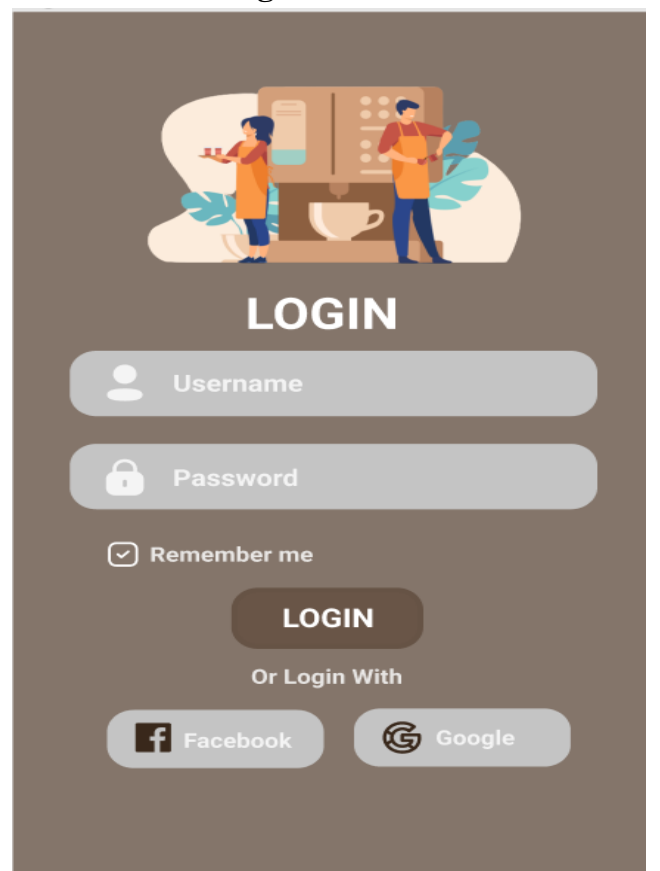

Gambar 7. Layout Login

Layout login digunakan oleh user sebagai pintu gerbang masuk aplikasi. Pada layout ini user akan diminta untuk memasukkan username dan password yang sudah teregistrasi di sistem.

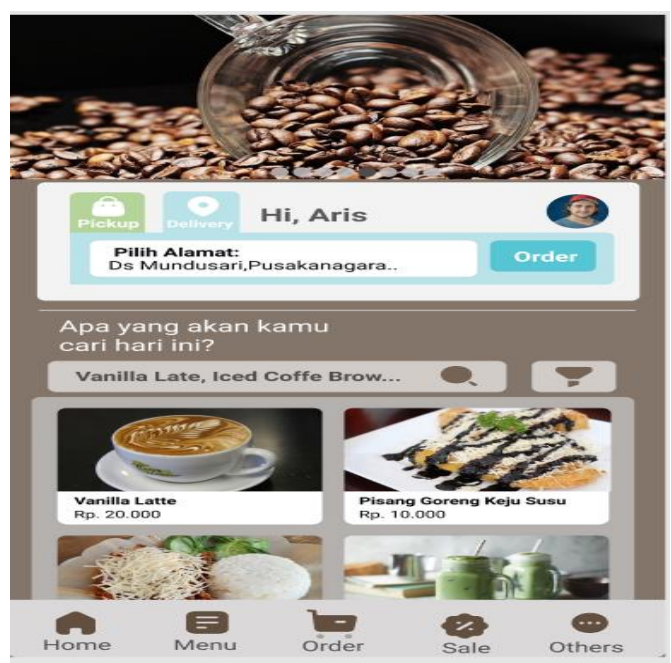

Gambar 8. Layout Utama 1

99 ISTMIK Dian Cipta Cendikia Kotabumi 
(2) Delivery Desa Mundusari, Pusakanagara, Su...
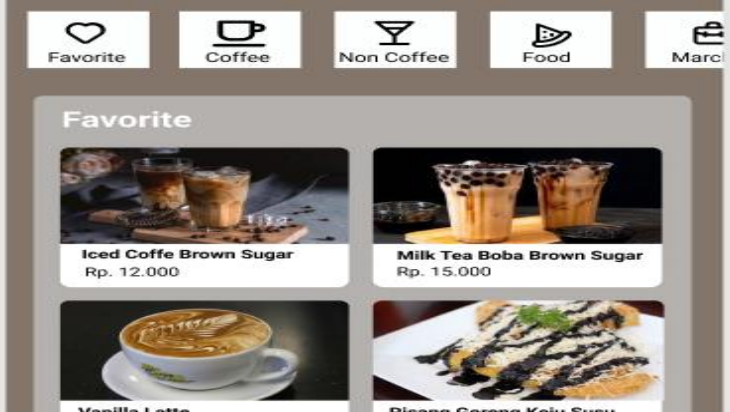

Vanilla Latte
Rp. 20.000
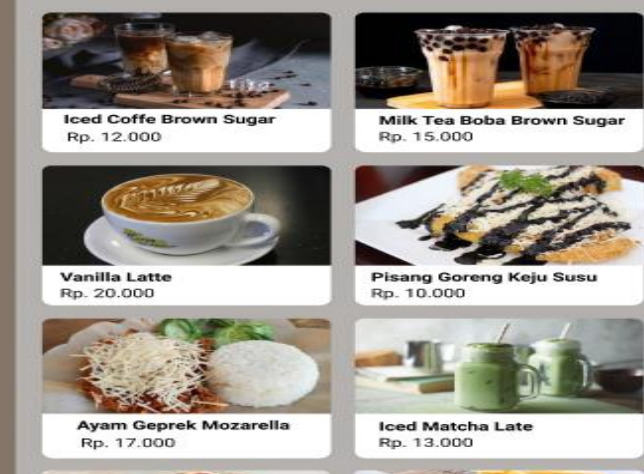

Pisang Go
Rp. 10.000

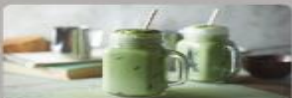

Iced Matcha Late
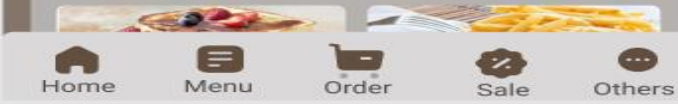

Gambar 9. Layout Utama 2

Layout utama ini akan menampilkan menu-menu yang yang disediakan oleh Kedai kopi. Tampilan yang disajikan adalah gambar dari menu makanan atau minumannya, nama menu dan harga.

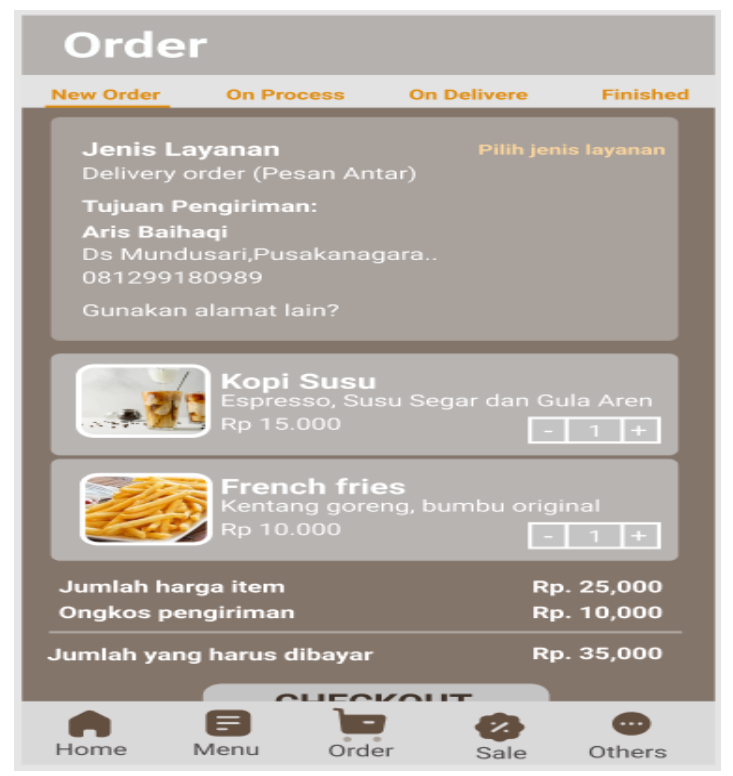

Gambar 10. Layout Order

Layout order menampilkan data menu makanan atau minuman yang sudah dipilih oleh user. Disini user dapat menambah atau mengurangi jumlah menu makanan atau minuman yang sudah diorder dan juga dapat melihat total harga dan ongkos kirim, yang jika sudah disetujui user tinggal mengklik tombol check out.

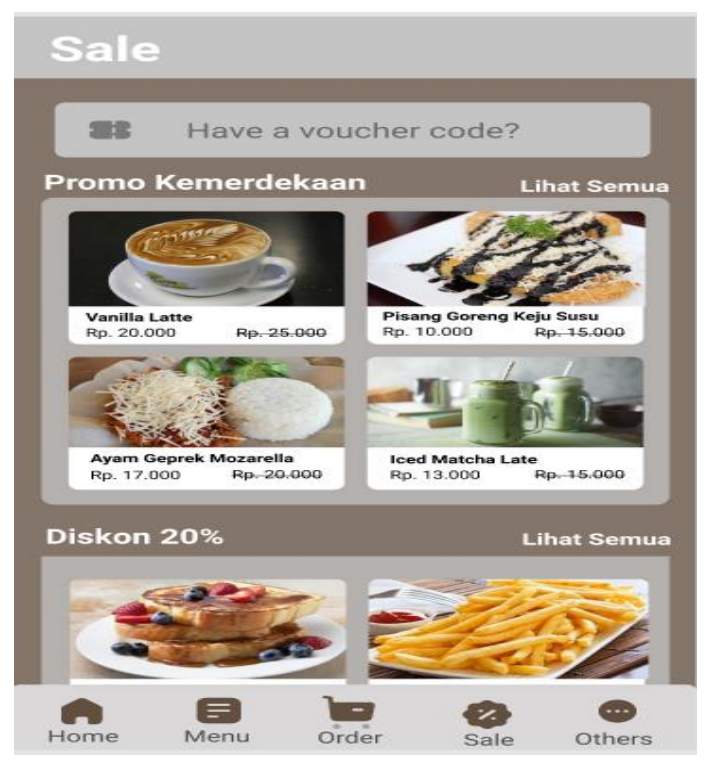

Gambar 11. Layout Sale

Layout Sales serupa dengan layout utama, namun yang ditampilkan adalah menu makanan atau minuman yang di set sebagai sales, diskon dan campaign lainnya yang dilakukan oleh pengelola kedai.

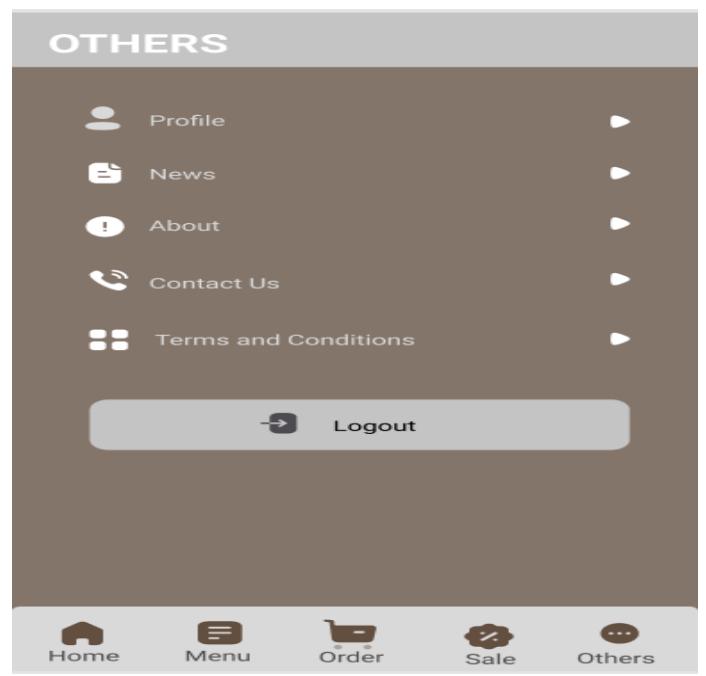

Gambar 12. Layout Others 
Layout others menampilkan informasi profil user, news dari kedai kopi dan lain-lain yang sifatnya umum.

Pengujian aplikasi dilakukan dengan menguji fungsi-fungsi dari aplikasi yang telah dibuat mencari kesalahan/bug pada sistem. Pengujian aplikasi dilakukan agar sistem yang dibuat berjalan sesuai dengan yang diharapkan dan dapat memenuhi kebutuhan pengguna. Pengujian aplikasi ini menggunakan teknik pengujian yaitu pengujian alpha dan pengujian beta. Pengujian alpha menggunakan metode Blackbox yaitu pengujian fungsi-fungsi aplikasi secara langsung tanpa memperhatikan alur eksekusi program. Pengujian ini dilakukan dengan memperhatikan apakah fungsi telah berjalan sesuai rancangan dan sesuai yang diharapkan. Tabel I adalah hasil pengujian dari aplikasi yang telah dilakukan.

Tabel 2. Pengujian Sistem

\begin{tabular}{|c|c|c|c|}
\hline $\begin{array}{c}\text { Fungsi } \\
\text { yang } \\
\text { diuji }\end{array}$ & Kondisi & $\begin{array}{l}\text { Output yang } \\
\text { diharapkan }\end{array}$ & Status \\
\hline Login & $\begin{array}{l}\text { Login } \\
\text { menggunakan } \\
\text { akun google }\end{array}$ & Sukses login & Valid \\
\hline Home & $\begin{array}{l}\text { Menambahkan } \\
\text { menu pada } \\
\text { keranjang }\end{array}$ & $\begin{array}{l}\text { Sukses } \\
\text { menampilkan }\end{array}$ & Valid \\
\hline Menu & \begin{tabular}{l}
\multicolumn{2}{l}{ Menambahkan } \\
data menu \\
sesuai dengan \\
kategori
\end{tabular} & $\begin{array}{l}\text { Sukses } \\
\text { menampilkan }\end{array}$ & Valid \\
\hline Order & $\begin{array}{l}\text { Menampilkan } \\
\text { data pesanan } \\
\text { yang sedang } \\
\text { diproses }\end{array}$ & $\begin{array}{l}\text { Sukses } \\
\text { menampilkan }\end{array}$ & Valid \\
\hline Sale & $\begin{array}{l}\text { Menampilkan } \\
\text { menu yang } \\
\text { sedang promosi }\end{array}$ & $\begin{array}{l}\text { Sukses } \\
\text { menampilkan }\end{array}$ & Valid \\
\hline Others & $\begin{array}{l}\text { Menampilkan } \\
\text { data akun, } \\
\text { kontak dan } \\
\text { about aplikasi }\end{array}$ & $\begin{array}{l}\text { Sukses } \\
\text { menampilkan }\end{array}$ & Valid \\
\hline
\end{tabular}

Berdasarkan hasil pengujian dari masing-masing proses pada Tabel I, dapat dilihat setiap fungsi valid, maka dapat disimpulkan bahwa aplikasi ini berjalan sesuai yang diharapkan. Pengujian beta dengan kuesioner tanggapan pengguna terhadap aplikasi tersebut. Pengguna terlebih dahulu mencoba aplikasi kemudian pengguna diminta untuk memberikan tanggapan melalui kuesioner. Pengujian aplikasi melibatkan 10 orang pengguna dengan memberikan beberapa pertanyaan. Hasil pengujian dapat dilihat pada Tabel berikut ini.

\section{KESIMPULAN}

Dalam rancang bangun aplikasi pemesanan menu kedai kopi berbasis android ini dikembangkan menggunakan aplikasi mobile yang diharapkan dapat mengurangi angka penyebaran kasus virus corona dan memudahkan para pelanggan melakukan transaksi pemesanan menu tanpa harus berkunjung ke toko.

\section{DAFTAR PUSTAKA}

[1] Noertjahyana, A. (2002). STUDI ANALISIS RAPID APLICATION DEVELOPMENT SEBAGAI. Jurnal Informatika, 74 .

[2] F Bachtiar;et al. (2020). Edukasi Mengenai Dampak Penggunaan Smartphone. Jurnal Abdimas Unwahas, 5, 28-32.

[3] Hidayat, H. T., Amin, H. A., Mursyidah, Atthariq, Safriadi, \& Mahlil. (2021). OPTIMALISASI PENGGUNAAN ECOMMERCE BAGI PELAKU UMKM DI MASA. The 2nd Seminar Nasional ADPI Mengabdi Untuk Negeri Pengabdian Masyarakat di Era New Normal, 50-51.

[4] Payara, G. R., \& Tanone, R. (2018, Desember 3). Penerapan Firebase Realtime Database Pada. Jurnal Teknik Informatika dan Sistem Informasi, 405. Retrieved from https://dx.doi.org/10.28932/jutisi.v4i3.8 70

[5] Pricillia, T., \& Zulfachmi. (2021, Maret). Survey Paper: Perbandingan Metode Pengembangan Perangkat Lunak(Waterfall, Prototype, RAD). Bangkit Indonesia, 7-8.

[6] SATGAS COVID-19. (2021). Beranda. 
Retrieved from Covid19:

https://covid19.go.id/

[7] Setiawan , R., \& Nugroho, W. (2021,

September). Rancang Bangun Aplikasi

Pemesanan Makanan Berbasis Android.

Journal of Information Systems and Informatics, 3, 338-339.

[8] Setiawan, R., \& Munajah, R. (2020). Evaluation of the Application of Online. TEM Journal, 9, 1994-1999.

[9] Suarantalla, R., Nugroho, F. A., \& Hermanto, K. (2020, Juli). RANCANG BANGUN APLIKASI PEMESANAN MAKANAN BERBASIS. Jurnal Teknik dan Sains, 1.

[10] Utama , D., Johar, A., \& Coastera, F. F. (2016, September). APLIKASI PEMESANAN MAKANAN DAN. Jurnal Rekursif. 